\title{
Government as a Key Duty Bearer in Transition Reforms from Socialism to Capitalism-The Case of Albania
}

\author{
Arlinda Ymeraj, (Assoc. Prof. Dr.) \\ European University of Tirana, Albania
}

Doi:10.19044/esj.2018.v14n32p84 URL:http://dx.doi.org/10.19044/esj.2018.v14n32p84

\begin{abstract}
The paper "Government as a key duty bearer in transition reforms from socialism to capitalism - the case of Albania", addresses the way in which the government should exercise its power to ensure that citizens have equal access to social welfare services, enjoying their rights. Albania, like other Central and Eastern European countries experienced the past socialist system, which failed. The failure of the socialist system was the failure of the state: in political, economic and social terms. As far as economic policies are concerned, all data demonstrate the collapse of socialism, because the system was based on inefficiency, which eroded growth. Regardless of the principles of communist regimes adopted in former communist countries' Constitutions, the past system brought neither equity nor justice, and therefore instead of "social cohesion", the contradictions among social groups and categories, deepened.
\end{abstract}

After the failure of socialism, Albania embarked on the new path aimed at establishing democratic regimes through the protection of human rights and at raising the standard of living. Albania has been proactive in ratifying international conventions relating to human rights in general and to vulnerable groups. Very recently, on June 2014, the European Council granted Albania candidate status, as a recognition for the reform steps undertaken in harmonizing its domestic organic laws and legislation with international standards. As part of these twin obligations from UN intergovernmental and EU processes, Albanian governments after the 90s have been progressively taking measures vis-à-vis efficient allocation of resources and effective distribution of social welfare. Nevertheless, Albanian citizens live in a dire reality.

Therefore, after 25 years of transition, one of the main goals of reforms, "Efficient allocation of resources to boost growth and effective distribution of social welfare to enhance equity", seems not to have been achieved. Undoubtedly, this influences the controversial opinions about the 
government's control vis-à-vis government's mode of functioning, advancing arguments that examine whether it is a question of abuse or that of concentration of power.

Keywords: Government, human rights, welfare, transition reforms.

\section{Introduction:}

The paper "Government as a key duty bearer in transition reforms from socialism to capitalism - the case of Albania", addresses the way in which the government should use its power to ensure that citizens have equal access to social welfare services, enjoying their rights. The role of government in postcommunist countries attracted the attention of researchers since the beginning of transformation, from centrally planned to market economy. The cases of transition reforms in Central and Eastern European countries, including Albania have shown that rapid transformation from a centralized to a liberal model cannot be realized without a strong and courageous intervention of the government.

Albania, like other Central and Eastern European countries experienced the past socialist system, which failed. Analysis of political economy of socialism as well as the way in which it was implemented in Albania clearly demonstrates the failure of the socialist system, which was a failure of the state: in political, economic and social terms. From a political point of view, it was a failure because the political power of the government was based on the oppression of human rights, dictatorship and authority. As far as economic policies are concerned, all data demonstrate the collapse of socialism, because the system was based on inefficiency, which eroded growth. Regardless of the principles of communist regimes adopted in former communist countries' Constitutions, the past system brought neither equity nor justice, therefore instead of "social cohesion", the contradictions among social groups and categories, deepened.

Artur M. Okun (1975), less than a half century ago, argued that "Although capitalism and democracy are really a most improbable mixture, maybe that is why they need each other - to put some rationality into equality and some humanity into efficiency". Due to complexity of political, economic and social transition reforms, CEE countries needed "strong governments" to confront with "Pareto Efficiency Theorems" and guarantee their effective implementation. However, crisis, political tensions and wars in the region as well as poverty, social exclusion and corruption, force us to challenge some of our conventional theories on the state, society and the economy.

The radical nature and rapid pace of transformation in the former communist countries has unleashed new forces for both positive and negative change, particularly in the fields of economic growth and social development 
(Ruli \& Hoxha, 2002). After the failure of socialism, Albania embarked on the new path aimed at establishing democratic regimes through the protection of human rights and at raising the standard of living. Albania has been proactive in ratifying international conventions relating to human rights in general and to vulnerable groups. Very recently, on June 2014, the European Council granted Albania candidate status, as a recognition for the reform steps undertaken in harmonizing its domestic organic laws and legislation with international standards. Probably next year, the negotiations regarding the European Union membership status, will be initiated. As part of these twin obligations from UN intergovernmental and EU processes, Albanian governments after the 90 s have been progressively taking measures vis-à-vis efficient allocation of resources and effective distribution of social welfare. Nevertheless, Albanian citizens live in a dire reality.

Albania remains one of the poorest countries in Europe with high absolute and relative poverty rates. The number of people living in poverty even increased from 12.4 percent in 2008 to 14.3 percent in 2012 (CCA Albania, 2015, p.22), and extreme poverty rose from 1.2 percent in 2008 to 2 percent for both urban and rural areas in 2012 as well as child poverty from 18,5 to 20, 1 percent. Despite the country's achievements in terms of economic growth, the benefits of economic development have not been evenly distributed. The country's Gini coefficient of 34, 5 (2013) is the third highest in the region and the pattern of the Gini index in the last two decades seem to be indicating growing inequalities (Ibid).

Albania also remains one of the most corrupt countries of the world and the most corrupt in the Balkans, together with Kosovo, ranked 110 out of 175 countries (http://www.transparency.org). The October 2016 EU Progress report on Albania recognizes that law enforcement remains a particularly serious problem, whilst the politicization of public services, dominates the functioning of public administration at all levels of governance. Beyond lack of coordination and other management constraints, the existing monitoring mechanisms of social welfare policies fail to reduce social exclusion, especially among vulnerable groups, whose rights are neglected.

Therefore, after 25 years of transition, one of the main goals of reforms, "Efficient allocation of resources to boost growth and effective distribution of social welfare to enhance equity", seems not to have been achieved. Undoubtedly, this influences the controversial opinions about the government's control vis-à-vis government's mode of functioning, advancing arguments that examine whether it is a question of abuse or of concentration of power.

This paper is composed of four sections in addition to the introduction. Section 1 explains whether Central and Eastern European countries need a government and of which type. Section 2 deals with the reasons why the 
government should intervene in CEE countries. Section 3 examines the Albanian experience, advancing some arguments which emphasize the crucial role that the government must play to ensure law enforcement, while the last section formulates some conclusions, tackling the multidimensionality of reforms as well as the shared responsibilities among all stakeholders, which again should be encouraged by the government.

\section{Section I: Do the Eastern European countries need a government?}

Whereas the theory of the state's role in capitalism is developed and many arguments are known, the role of the state in post-communist countries is still unclear. During socialism, the socialist state was the perfect model of an authoritarian regime, in which the government ran the country through a strict hierarchical system of decision making. Despite the strict measures to control the implementation of all political, economic and social policies, this system failed. So, why is the government important? What is its role?

Some politicians do not understand that the socialist system did not fail because the state had too much power, but because it was badly organized. Other politicians argue that the economic role of the state must be separated from its political role, contending that the state in the past failed because of its inability to separate economic issues from the political ones. But, as long as political power stems from economic power, it is not possible to separate economics and politics. They are linked with each other. It was true in the past and it is so today. "Economics will remain profoundly political, not only because this is the case in every politico-economic system, but because in the specific context of Central and Eastern European countries, the task of economic transformation presents unprecedented political challenges" ( Batt, 1991, p.73).

Underlining that economics and politics are linked with each other, raises another question: where is the line between the state and the market. In a totally free market economy based on the model of liberals, there is only the market. In socialist systems, there was only the state. What lies in between? What are the features on which the role of the state vis-à-vis the market depends? It is the efficiency of the government to implement its duties, to provide institutions and appropriate legal framework, to supervise how they are working and to ensure that citizens can equally access public services. Therefore, only the government bears the responsibility to provide welfare, to distribute and re-distribute revenues, to find and implement policies which promote economic growth and harmonize it with social development.

Central and Eastern European countries in the process of transition from a centrally planned to a market economy face similar political, social and economic challenges. Whereas political transformation is desirable for the people, economic and social transformation is painful. From a public opinion 
point of view, the economic and social role of the state are considered more important. The implementation of transition reforms requires strict macroeconomic stabilization policies implemented alongside privatization, liberalization of prices and trade, fiscal and monetary policy; banking reform and opening of the economy. The social pain which accompanies the implementation of these policies is the natural outcome of transition. But people are not prepared to tolerate such a situation. They have other expectations. Moreover, there were strong expectations that the new 'democratic' governments, supported by International Institutions, would have been capable to bring CEE countries closed to the most developed countries. Unfortunately, this belief did not come true. Figure 1 shows the differences in GNI per capita in some CEE countries, including the best performing ones, compared to OECD and High Developed countries. As we can observe, even Slovenia, Slovakia and the Czech Republic (the best performing economies among CEE) lag behind OECD and High Developed Countries.

Figure 1: GNI per capita, 2015

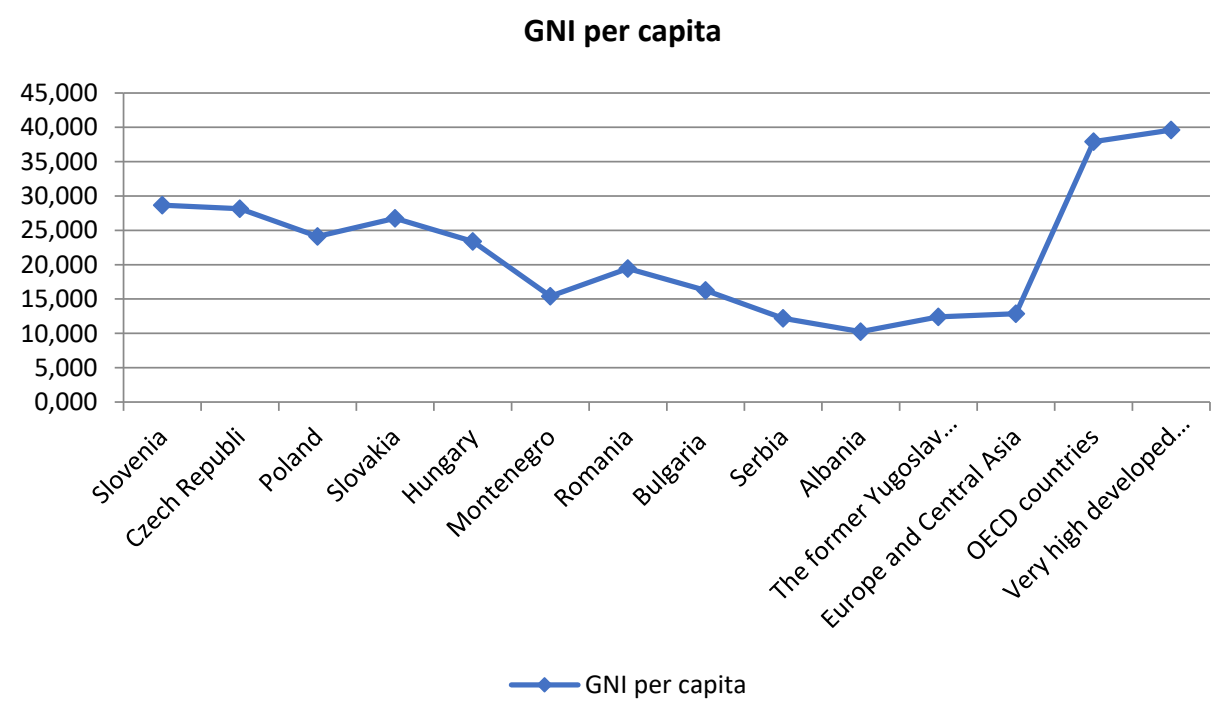

Source: Human Development Report, 2016

In such a challenging environment, the economic and social goals of transformation can be reached only by strong governments. A "strong government" in the new reality of Central and Eastern European countries has nothing in common with the past models of political and ideological power concentration. In the deep transition process, such as Central and Eastern European countries are undergoing, a strong government is the one which takes courageous decisions leaving alone superficial and short term interests. 


\section{Section II: Why should a government intervene?}

"The duties of the state are......first...that of protecting the society from the violence and invasion of other independent societies;......second...that of protecting, as far as possible, every member of it;..third....that of erecting and maintaining those public institutions and those public works which, though they may be in the highest degree advantageous to a great society, are of such a nature, that the profit could never repay the expence to any individual or small number of individuals" (Smith, 1776, cited by Barr, 1987, p.3).

One of the greatest liberal thinkers, Adam Smith, underlines three important duties of the state, namely economic, social protection and developmental roles, although he was a strong advocate of "laissez faire" and considered individual freedom and initiative, the best alternatives to develop the world in harmony. Despite the changes in the international political economy and environment, these three fundamental responsibilities of the state stand at the basis of every social system.

The question of the role of the state in the market economy has been and continues to be a controversial one. There are many advocates who explain the reasons why the state should intervene. There are also opponents who support the idea that the role of the state must be reduced. Despite ongoing debate, the modern theory of the state advances some arguments why the state should intervene in the market economy. However, there is a big distinction between the government's challenges in developed countries and in countries which very recently embarked into market economy.

In developed countries, let's say in classical market economies, the government intervenes to regulate, to adjust, to improve the general functions of the economy, fueling in this way the prosperity of the whole society. Progress has been gradual and based on the contribution of previous generations. In former socialist countries, the government needs to intervene to establish and at the same time to improve the functioning of the economy, in a rapid process, in which the legacy from the past is poor. Figure 2 shows the gaps in Human Development Index(HDI) and Gender Development Index (GDI) among CEE, OECD and High Developed countries. 
Figure 2: HDI and GDI in some EEC compared with OECD and Very High Developed countries, 2015

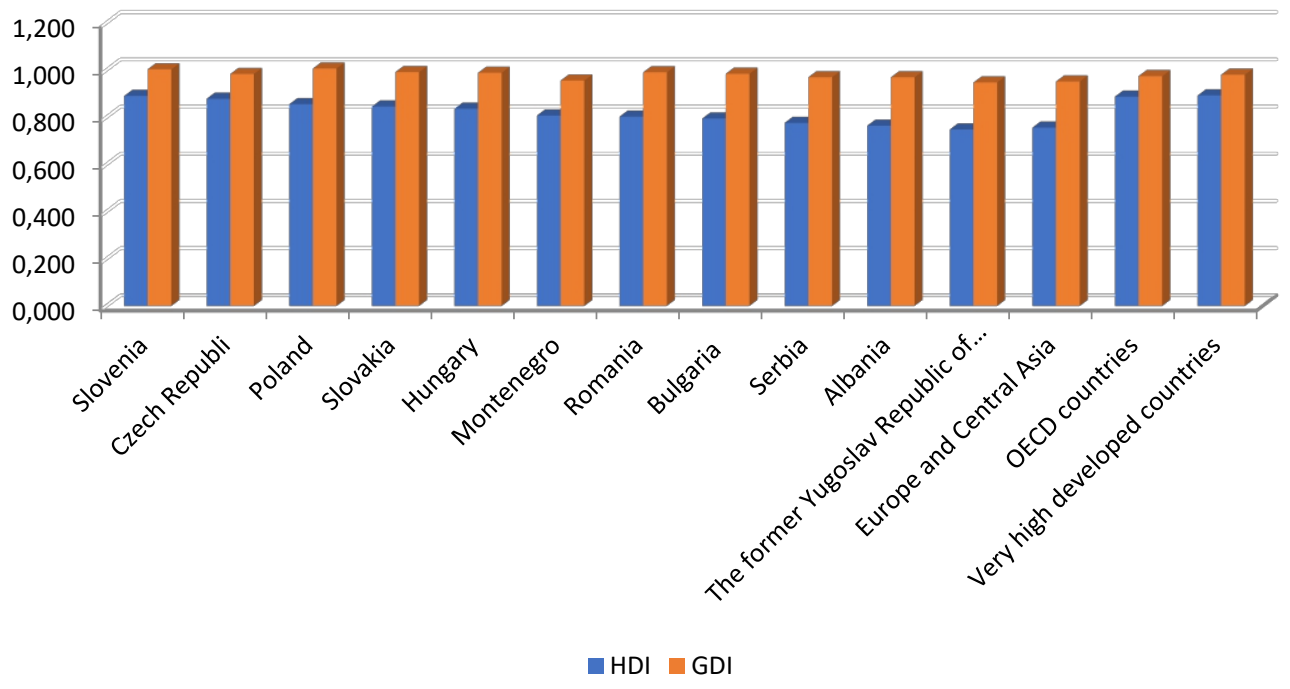

Source: Human Development Report, 2016

In modern societies, the government is accountable to ensure that every citizen enjoys its rights, while in developing countries, governments must establish the institutional frameworks in which human rights take place, and then struggle to realize them. Regardless the ratification of the most important UN Conventions, in addition to the Human Rights Declaration by all CEE countries, many people's rights are denied.

Data show that alongside the transformation, inequalities increased. Figure 3 demonstrates gaps in some key welfare indicators like income, life expectancy and education. With some exceptions, like Slovenia, Czech Republic and Slovakia, almost all CEE countries experience similar problems. 
Figure 3: Inequalities in welfare indicators in EEC countries compared with OECD and High Developed countries, 2015

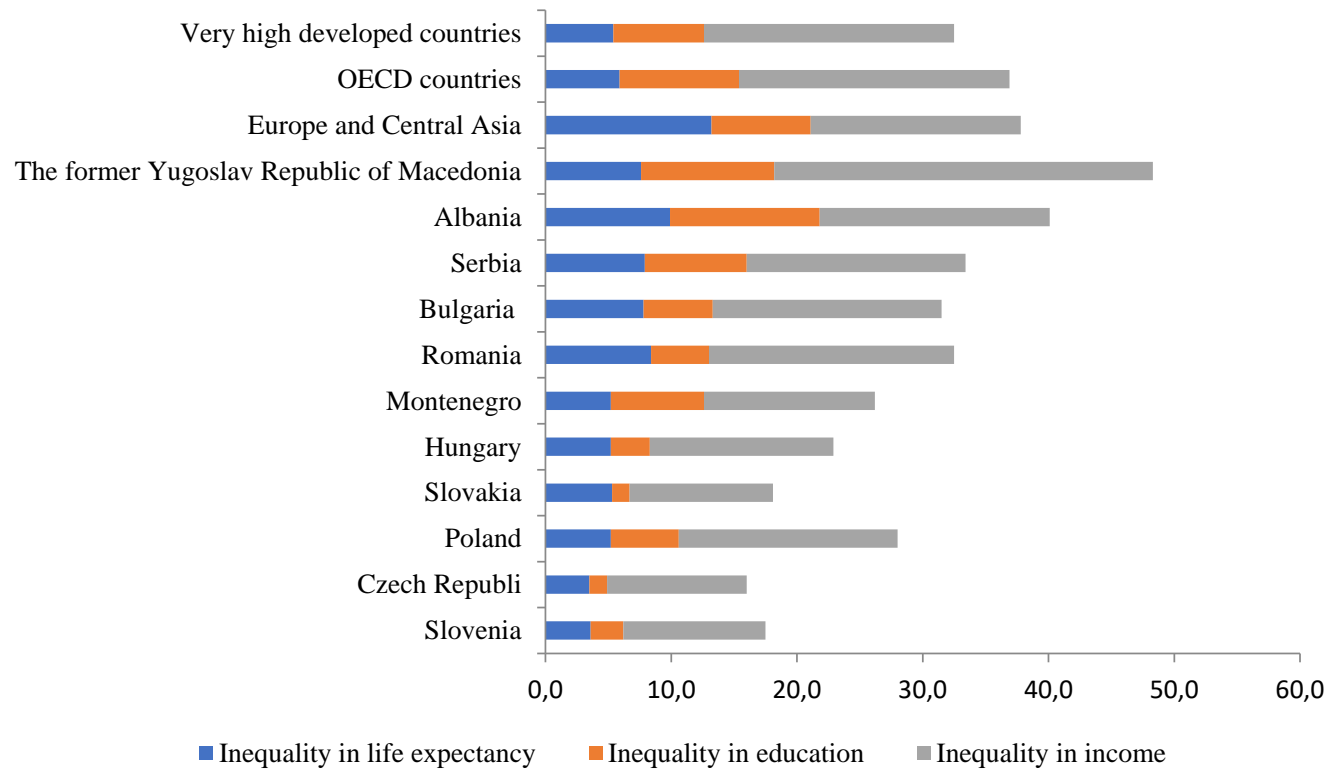

Source: Human Development Report, 2016

The government is responsible for the success of transition period. From this difficult task stems the triple role of the state in post-communist countries: it has economic role, because it establishes and improves a new economic system, to encourage the development of markets and competition; it founds the systems which protect citizens from the shocks of transition (social protection role); it supports institutions and civil society to interact to educate people with the rules of democracy, while encouraging them be socially included (social development role).

\section{Section III: The three fundamental roles of government during transition from socialism to capitalism}

\section{A. The economic role of the state in post-socialist countries}

Although the economic role of the state in post socialist countries is still undefined, some lessons from western experience can be applied. The government and not political parties or separate social groups is the author of economic changes. These changes lay the foundation for all the major transformations from the former system to the new one. The economic role of the state in post-communist countries is very complex and multi-dimensional, totally different from the past. During transition and later, state should strongly intervene to distribute and redistribute revenues and ensure the citizens' equal access to economic resources. Only the government can co-ordinate 
stakeholders' goals, assessing short term advantages of economic policies versus sustainable growth as well as their impact on people's welfare.

It seems there is no difference between the economic role of the government in developed countries and in those which have recently embarked on market economy. Notwithstanding, the implementation mode of policies, the functioning of government and the breadth of the process, are different. In post-socialist countries, the government must create and regulate at the same time.

Although economic tools are the same, like the liberalization of prices and trade, the privatization of state ownership properties, tax policy, encouragement of savings or investments, banking reform and the tight control over public expenditures, their effective use and the citizens' equal access to economic opportunities, are not the same. Whereas in Western countries, the government takes decisions and implements policies to improve the people's welfare, in CEE countries, the government has to implements those policies which should create the affluence in the future, for the next coming generation. Therefore, a stronger political will is required.

\section{B. The social protection role of the government in CEE countries}

The real challenge that Central and Eastern European countries faced was social reform. There are several different social policy models, which have all emerged from the historical inheritance of its countries of origin. Scholars are talking about the "Germany-, Great Britain-, Scandinavian- and Japanesemodels". The post-socialist countries in the CEE do not have a model yet as it is still emerging. It is a society in transition, still finding its way.

The new economic and social situation that followed the collapse of the communist regime has exposed the problem of poverty, which required manifest and urgent treatment. Analysis suggests that the institutional framework for social policy in countries in transition had to be transformed to respond to the changes occurring from processes of international economic integration. In particular, the state's role in regulation of social policy depended on profound governance reform.

Literature of the mid-1990 argues for the necessity of social protection systems in the newly emerging market economies. The literature that describes some of the models of social policy systems in Eastern European countries also describes the main goal of the transitional reforms in these countries. Despite the important steps taken by respective governments to transform social relationships, the key objective was 'maintaining the macroeconomic balance', meaning 'there was a need for policies to contain costs'. Thus, the social protection was focused more on keeping down social unrest than promoting people to shift actively from their situation. It was argued by the necessity to protect quantitatively the people, because of the spread of poverty in these 
countries. Given the peculiarities of the first stage of the transition, the models worked well.

During the last years of transition, the situation changed from an initial focus on helping people cope with massive unemployment due to the closing of large state enterprises, to a focus on development and poverty alleviation. While some progress has been made, overall the reform efforts have missed their mark and there is a continuous high risk of increasing poverty, inequality and social exclusion. Despite broad legislative reform related to human rights, the existing mechanism of sectoral social policy has little effect on the reduction of social exclusion, especially among vulnerable groups whose rights are neglected due to their fragmentation and absence of coordination in their implementation. The Government should take all necessary measures to ensure that all legislation and policies are harmonized and priority is given to disadvantaged groups in national social and economic plans with budgetary allocation.

\section{The social development role of the government}

Education and health services have existed in the socialist system. Even more, they have been considered as one of the advantages of the socialist economy. Thus, it seemed that there was no need for an intervention from the government in these fields, because there was nothing to change. Nevertheless, two issues had to be considered: first, the quantity in which these public goods must be produced and second, their quality. Government's intervention is required to ensure that all citizens have equal access to education and can benefit from pertinent health care services.

Although the spread of literacy was an advantage of the socialist system, central planning and political control of programs and teachers in the schools of all levels limited individual choices, encouraged dogmatic teaching and affected in this way the destruction of society values. Therefore, improving the quality of education and training is vital for the future economic development of former communist countries.

Last, but not the least, the role of the government is important to lay the foundation for the development of civil society, for the encouragement of partnerships and harmonization of stakeholder's strategies and frameworks.

These three main duties cannot be separated, because on the one hand they reflect the role of the government in the establishment and regulation of the new political, economic and social order and on the other hand, they affect the creation of a new relationship between the state and citizen, which is crucial for the success of reforms. 


\section{Section IV: The case of Albania}

\section{A.The state of welfare and human rights}

Albania, a small country in the Balkan peninsula, with an area of 28.748 square kilometers and a population of 2.774 million (INSTAT, 2013), despite its wealth of natural resources, was and remains one of the poorest countries in Europe with high absolute and relative poverty rates. The number of people living in poverty increased from 12.4 percent in 2008 to 14.3 percent in 2012, and extreme poverty rose from 1.2 percent in 2008 to 2 percent (INSTAT, 2008, 2012) for both urban and rural areas in 2012 as well as child poverty from 18,5 to 20 , 1percent (UNICEF, 2015).

Despite the country's achievements in terms of economic growth, with GDP Annual Growth Rate averaged 4.16 percent from 1996 until 2016 (http://www.tradingeconomics.com), the benefits of economic development have not been evenly distributed. The country's Gini coefficient of 34,5 (2013) is the third highest in the region and the pattern of the Gini index in the last two decades seem to be indicating growing inequalities (UNICEF, 2015). Moreover, inequalities in income also prompted a major loss in inequality adjusted Human Development Index (Figure 1 and 2).

Health and education indicators are among the lowest within CEE countries. Although life expectancy in Albania has increased steadily in the past twenty years in both sexes (in males: from 67 years in 1990 to 73 years in 2012; in females: from 71 years in 1990 to 75 years in 2012, child mortality, infant mortality and maternal mortality rates are high in comparison with average rates for EU countries (CCA, 2015).

In Albania, the education system lags behind of being "inclusive for all". Discrimination partly stem from mentality /social norms as well as the low attention to the implementation of antidiscrimination law and other normative disposition on disability. However, social protection mechanism bears the burden of not providing adequate support to groups of children already excluded or at risk of exclusion from the enjoyment of the right to education.

Corruption (figure 4) and organized crime are the most recurring themes throughout the citizens' considerations. Mismanagement of the system, lack of law enforcement, poor infrastructure, education and training, and poverty lay the foundation for informal capital flows and labor as well as corruption. This influences other development challenges, mainly on health care, judicial reform, employment and public management. 
Figure 4: Corruption Perception Index, 2014

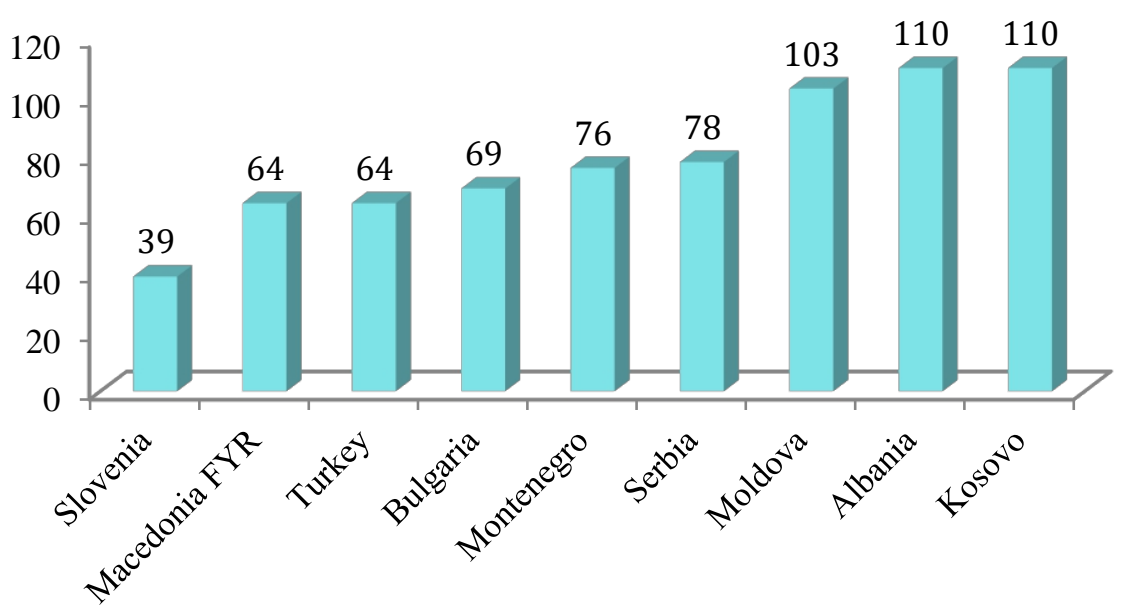

Ranking out of 175 countries

Source : http://www.transparency.org/

Although Albania has ratified almost all important international conventions and acts and has reported to several UN human rights committees, periodic reviews as well as data mentioned above demonstrate that Albanians' citizens do not equally enjoy their rights.

The Albanian government has reported on Millennium Development Goals progress since 2002 until 2010. By 2004, the eighth goal on developing a global partnership for development was formally adapted to the Albania MDGs, and a special 9th goal to establish and strengthen good governance was included. MDG reporting was nationally owned and helped to ensure that the promise of 2015 is kept by government by providing all stakeholders with a common, nationally owned framework for continued action towards the MDGs, which in turn feed directly into Albanian National Strategy for Development and Integration (NSDI).

However, with a HDI of 0,764 and GDI of 0,969 , Albania ranked respectively $95^{\text {th }}$ and $72^{\text {nd }}$ out of 187 countries on the 2016 Human Development Index (HDR, 2016). In general, the fragile growth rates as well as structural economic reform are not sufficient to ensure the achievement of the strategic priorities of the country.

\section{B.The legacy from the past and the "political economy" of transition.}

From a political point of view, Albania has been characterized by historically heterogeneous governance, marked by striking disregard of the stages of social development, which have had a huge impact on the development of economic and social factors. In 1991, Albania embarked on a 
deep political and economic reform aimed at establishing a democratic regime through the protection of individual rights and at raising the standard of living through a free market economy. From that time until 1995, it was considered a successful country with great prospects for the future. "Stabilization was soon reached and the good performance of the macro-economic indicators identified Albania as the model pupil of the IMF" (Giurato, 1997, p.63). Unfortunately, in early 1997, the state collapsed and political instability ensued.

The collapse of the state was not a sudden phenomenon. Rather, it was a process, in which government's policies bear the burden. Albania's case is one of the most difficult compared to other Eastern European countries which experienced transition reforms before Albania due to many differencies closely conencted with the legacy from the past.

Albania's economic performance in the past was different from some Central and Eastern European countries, (such as Czech Republic, Poland and Hungary) models of which Albania chose to copy during transition. Unlike those countries (which were considered highly industrialized and developed), at the end of the Second World War, Albania was an agricultural country, with practically no industrial base, widespread illiteracy (almost 85 percent of population) and with no infrastructure. During the five decades after the Second World War, thanks to the interest of the communist regime in heavy industry, the share between agricultural and industrial sectors changed, but the agricultural sector continued to play a major role. Although industry was developed comparable to the level in the past, it was backward compared to other Central and Eastern European countries. Albanian productivity of capital was the lowest among former socialist countries. On the eve of transformation from socialism to capitalism, the data about economic performance of the former socialist bloc showed the gap between Albania and other former socialist countries. Albania was described as "the poorest country in Europe with standards of living resembling third world countries" (IMF, 1992, p.1).

Albania, officially, belonged to the former socialist bloc, but in fact it was totally isolated, the least known country in Europe and perhaps one of the least known in the world. Whereas other Eastern European countries strengthened economic relations inside the bloc, implementing the division of labor, specialization and a better harmonization between the resources of raw materials and the development of sectors of industry, developing foreign trade, the Albanian authoritarian regime imposed self-isolation for political reasons, limiting external contacts and trade.

The Albanian authoritarian regime implemented an economic model which evolved strictly along the lines of the classic Stalinist model, totally influenced by political and ideological factors. Other Eastern European countries, after the $60 \mathrm{~s}$, undertook some steps to liberalize economic relations 
and to privatize a few activities, thus creating a little space for a market economy, especially in the agricultural sector, small business and retail trade. By contrast, the political regime in Albania was strengthened over time. The former socialist bloc also allowed some limited foreign investments, deviating from strict Stalinist principles of economic development, whereas Albania abolished totally private ownership, foreign investments and loans.

During the last years of socialism, the political and economic crisis in Albania was deeper than that experienced by other reforming socialist countries because of sharp social problems and the lack of protection structures. Most of other Central and Eastern European countries had initiated some basic social services for vulnerable groups and people at high risk of exclusion, based on the old tradition of social work, which used to exist before the WWII. In contrast, Albanian government did not acknowledge the existence of poverty or social disparities, therefore when Albania embarked on the new path, the institutions were totally unprepared to help the people in need and protect them from the shocks of transition.

\section{C.Governments' responsibilities vis-à-vis the results of transition reforms}

The last 25 years saw a multifaceted development of the country, associated by a radical transformation of the market, institutions and social relations. However, the evidence and facts provided here advance the idea that the results should have been different. The transition reforms could not bring in wealth and prosperity for people.

The imitation of the Czech and Hungarian experiences without confronting them with the Albania's mentality, traditions and institutional culture inherited from the past, on the one hand and the weak implementing and monitoring capacities of the government institutions, on the other, contributed to the failures and time to time to crisis. In particular:

i)The liberalization of the relations between state and citizen, state and market, economy and politics affected the new attitude of the people, the idea that democracy is a system in which everybody has only rights and no responsibilities. As it was described above, the economic and political development of Albania is characterized by the historically heterogeneous governance marked by striking disregard of the stages. Albania passed from the most centralized to the most opened market economy, while the government's pattern shifted from a "controller" to an "observer".

ii)The fast development of the informal sector, including the informal labour market substituted the role of institutions. Over the years, the governments as they were not able to provide affluence for citizens in a short time and without much effort supported informal economy hoping that in this way it would secure the necessary political support to continue the reforms and the governance in stable conditions. Although the government has gradually 
reduced the size of informal economy, it still is an important producer of GDP. Moreover, the government legal actions have not yet touched "informality of labor market".

iii)The psychology of wealth at any cost, including illegal and criminal activities affected the establishment of "the new class of rich people", less educated and more arrogant. In addition to deep polarization of the society and the "growing gap" between the former middle class of intellectuals" and the" new class of entrepreneurs", the earned capital was invested in politics, instead of production. The governments' position of "observation" rather than of "the confrontation with the law" gradually transformed into "a dangerous governance model" characterized by the abuse of power.

iv)The lack of a democratic political culture and of trust on institutions hampered civic participation in decision making and governance. It is unlikely to believe that in such an unfriendly environment, civic watchdog mechanisms would ever function effectively.

v) The lack of critical thinking as a teaching methodology, combined with the abolishment of the alternative forms of education brought about a vacuum in educational system, which gradually destroyed the attitudes of shared responsibilities.

The Albania's case clearly describes a rapid process of transformation from a pure Marxist to a pure liberal model hence the new political system could not avoid crisis. The Albanian society missed the appropriate culture and knowledge to face with such a deep transformation, that is why the government would have guided the reforms intertwined with a broad and extensive civic education process.

\section{Conclusion:}

Central and Eastern European countries vary from each other not only in terms of economic development but in general. The differences in their levels of development are linked with the legacy from the past and the role of the government during transition.

However, could the transition have been different in Albania? The acknowledgement of this alternative does not seem feasible, because the whole transformative processes are linked with the legacy from the past. Nevertheless, it was the government's task to assess the pros and cons of reforms and the context in which these reforms would take place. Notwithstanding, beyond the governance model, there is the government's mode of functioning, recognizing that weak institutional capacities vis-à-vis law enforcement left room to abuse with power.

The cases of transition reforms in Central and Eastern European countries have shown that the rapid process from the centralized to a liberal model cannot be realized without a strong and courageous intervention of the 
government, because success of this process depends on the policies that the government followed and the abilities to implement them. The government is the linkage between privatization, foreign investments, financial policies etc. and the management that ensure their implementation. The role of government is not only to focus on the legal framework, but also to apply this framework through the decentralization of services and the consolidation of individual responsibilities. In contrast, the establishment of a legal system does not have any useful function and the triple role of the government, namely the economic, social and development one can't be harmonized.

By no accident these reforms are called "transition reforms". This means that the old system cannot be destroyed immediately. The process of evolution must follow in a natural and gradual way, substituting old relations slowly only when the new relations are created. The socialist system came to power through violence, damaging all values of the previous society, whereas the new system which aims to respect all human rights cannot be based on imposed transformation. Whether the government is able and is willing to respect this principle, can understand the domestic conditions and of reacting to them, depends on government itself as well as on the people's accountability.

\section{References:}

1. Bank of Albania (2010), Annual Report, Tirana Bank of Albania.

2. Barr, N.(1987), The Economics of the Welfare State, Great Britain, Biddles Ltd.

3. Barr, N. (1994), Labour markets and Social Policy in Central and Eastern Europe, New York: The IBRD.

4. Batt, J. (1991), East Central Europe from reform to transformation, London: Pinter.

5. Bird, G. (1992), Economic reform in Eastern Europe, E. Elgar: UK.

6. Blaas, W. and Foster, J. (1992), Mixed Economies in Europe, UK: Elgar Edward.

7. Derek, H. (1994), Albania and the Albanians, London: SRP Ltd. Exeter, 1994.

8. Donald Djatcho Siefu, Martin Njocke, Neba Cletus, (2018), Government Spending and Economic Growth in Cameroon, European Scientific Journal October 2018 edition Vol.14, No.28 ISSN: 1857 7881 (Print) e - ISSN 1857- 743168.

9. Elberly, D. (1992), The Essential Civil Society Reader, USA.

10. EC (European commission), Albania Progress Report (2016), Brussels.

11. Giurato, L.(1997), Transition reforms in Albania, Quaderni di economia a finanza-Anno VI - N.2/1997. 
12. Havrylyshyn, O., Meng,X.\&Tupy, M.L (2016), 25 Years of Reforms in

13. Ex-Communist Countries Fast and Extensive Reforms Led to Higher Growth and More Political Freedom, CATO Institute, Policy Analysis, No.795, July 12, 2016.

14. IMF (International Monetary Fund), (1992), Albania: from isolation toward reform, Annual Report of the Executive Board for the Financial Year Ended April 30, 1992 Washington, D.C

15. INSTAT (National Institute of Statistics) (2013), Population and house census, Tirana:INSTAT.

16. INSTAT (National Institute of Statistics), (2008,2012), Living Standard Measurement Survey, Tirana:INSTAT.

17. INSTAT (National Institute of Statistics) (1997-2010), Albania in Figures, Tirana:INSTAT.

18. Jorgoni, E.\& Ymeri, S.; (2014), The Future We Want, COUNTRY REPORT, Second phase of Post-2015, Development Agenda Consultations, Tirana: UNDP

19. MOLSA (Ministry of Labour and Social Affairs), (2000-2015), Statistics, Tirana: MOLSA.

20. National Strategy for Development and Integration (2007-2013)

21. National Strategy for Social Inclusion (2007-2013).

22. National Strategy for Social Inclusion and Protection, 2015 - 2020.

23. Ndajiya, A.\& Mato, K (2014), Labour/Government relations in Nigeria: A study of regulation (1999-2012), European Scientific Journal November 2014 edition vol.10, No.32 ISSN: 1857 - 7881 (Print) e - ISSN 1857- 7431

24. 207.

25. Ocun, M.A (1975), Equality and Efficiency, the Big Tradeoff, Washington, D.C.: Brookings Institution

26. Rose, R. (1998), Getting things done in an anti-modern society: Social Capital networks in Russia, Social Capital Initiative, Working Paper No.6, The World Bank.

27. Stiglitz, J. (1986), Economics of the Public Sector, USA.

28. Ruli, G.\& Hoxha, A.,(2002) Social Business and Social Exclusion in Transition Countries - The case of Albania, Tirana: UNICEF.

29. Tomes, I. (1997), The Social Right; Published by MLSAEO, Tirana.

30. UNCT (United Nations Country Team), (2015), Common Country Assessment, Tirana: UNCT

31. UNDP (United Nations Development Program), (2016), Human Development Report, United Nations Development Programme, UN Plaza, New York, NY 10017 USA

32. UNICEF (United Nations Children's Fund), (2015), The Situation Analysis of Children and Women in Albania, Tirana: UNICEF 
33. Vecernik, J (1995), Incomes in Central Europe, Institute of Sociology, Academy of Sciences, Prague

34. Ymeraj, A. (2003), Civil society and social care, European Institute of Social Services, University of Kent, Canterbury, UK.

35. Zamagni, S. (1997), The crisis of Welfare state: Government and social welfare, Milan: Mondadori. 